essentially allied to insanity and insisted that it should be treated medically and not as if it were a crime. It was mainly due to him that the Habitual Drunkards Act of 1888 and the Inebriates Act of 1898 were amended. During the fifty years of its existence, the subjects discussed by the Society have included the influence of heredity on alcoholism, alcoholism and child welfare, alcoholism and venereal disease, the use of alcohol in medicine, drug addiction as an international problem, ether-drinking and the cigarette habit. The Society, which consists of medical members and lay associates, aims at a scientific study of alcoholism and drug addiction, and has not a policy of total abstinence.

\section{Society of Dyers and Colourists}

Arrangements for the jubilee celebrations of the Society of Dyers and Colourists, to be held at Bradford at Whitsuntide, are in active progress. Inaugurated at a meeting in Bradford on May 14, 1884, the Society is the oldest of its kind in Great Britain. Special interest in the celebrations will be attached to the issue early next month of a jubilee number of the Society's Jour. nal, containing original articles by eminent authorities on the processes of dyeing and their development in the course of the past fifty years. In these, invention, scientific research and records of practical applications will receive full attention. It may be recalled here that the Society allots the Perkin Gold Medal at intervals, for conspicuous service to the tinctorial industries. By means of its award the synthesis of indigo, the discovery of viscose, of primuline, and of alizarine blue have been severally recognised.

\section{Geistige Arbeit}

THE object of a new periodical of this title which appears twice monthly (25 pfennigs per copy) is to give brief reviews of the progress and tendencies of modern scientific research. The subjects considered cover a wide field, including anthropology, political economy, agriculture, sociology and all the pure and applied sciences. There are articles on peasants and nomads, problems of German sociology, new concepts of natural science, methods of counting for statistical purposes, Paracelsus (a sketch), and many others. The contributors are chosen from the ranks of those who have done original work in their respective fields. In the article by Möglich dealing with the foundations of present-day physics, we find due acknowledgment paid to the epoch-making ideas of Planck and Heisenberg, but there are important omissions which detract from the value of the account. In highly compressed articles of this type, it is of primary importance that the authors should have not only a deep insight into their subjects but also a proper sense of values, if the services of a discriminating censor are not to be invoked. Goethe has said : "Die Vernunft ist auf das Werdende, der Verstand auf das Gewordene angewiesen". This remark applies particularly aptly to the present journal, which bears the sub-title "Zentralblatt für die gelehrte Welt". The article on Theophrastus Bombastus von Hohenheim, commonly called Paracelsus, is of interest as his name has recently come into prominence again as one of the first great experimenters in medical science-one hears of a Paracelsus Renaissance in Germany-in spite of a certain notoriety as a vagabond miracle-worker which he probably only partly deserved. His ideas, if not actual results obtained, undoubtedly exerted a considerable influence on later workers. The journal is published by Walter de Gruyter and Co., Berlin W.10, Genthinerstr. 38 .

\section{Philosophy of Science}

THe welcome co-operation between science and philosophy, which has become a distinctive feature of our time, is further illustrated by the appearance of a new quarterly, Philosophy of Science, which is published by the Philosophy of Science Association in the United States (Baltimore: Williams and Wilkins Co.; London : Baillière, Tindall and Cox. 6s. $9 d$.). This interesting publication sets itself the useful task of giving an organised expression to the growing interest among philosophers and scientific workers in classifying, and perhaps unifying, the programmes, methods and results of the disciplines of philosophy and of science. With this object in view, the editor, Prof. W. M. Malisoff, proposes as a research programme, the analysis of meaning, symbolism, definition, axioms and postulates, the study of the nature and formulation of theoretical principles, and questions of method and of the structure and hierarchy of the sciences. The first issue of the new journal contains a remarkable series of papers ; among the contributors are Prof. J. B. S. Haldane on "Quantum Mechanics as a Basis for Philosophy", D. J. Struik on "The Foundations of the Theory of Probabilities", Rudolf Carnap on "The Character of Philosophic Problems". The excellent presentation of the journal and the eminence of its contributors give an added value to its object and method which, no doubt, will appeal equally to scientific workers and to philosophers.

\section{Research in the Solomon Islands}

A REPORT on the work of the Templeton-Crocker Expedition to the Solomon Islands, 1933, has recently been sent to Nature by the Director of the Bernice P. Bishop Museum, Honolulu. The expedition left San Francisco on March 2, 1933, in Mr. TempletonCrocker's auxiliary schooner Vaca and returned on September 15 after conducting a preliminary ethnographical and medical survey of a number of islands in the Solomon group. The principal objective was the Rennell and Bellona islands, but before arriving there the expedition collected data bearing on tuberculosis and tropical diseases, as well as ethnographical material, at Sikiana, Tulalagi, Guadalcanar and Malaita. Advantage was taken of conditions on Rennell and Bellona, where bird and insect life are undisturbed and the inhabitants virtually unaffected by European contacts, to make extensive collections of birds, plants and insects and to record particulars relating to native life and customs, which appear to 
have suffered little change since the Polynesian ancestors of the inhabitants first arrived there twenty generations ago. It was also possible to arrange for an intensive study of the disease and general health of the population of one district. Blood samples for filaria tests and blood groups were obtained. On Bellona the party was fortunate enough to obtain cinematograph record of the annual firstfruits ceremony. A medical and health survey was also made on the islands of San Cristobal, Santa Anna and Santa Catalina. As a result of the expedition's work, 3,200 artefacts have been added to the collections of the museum in Honolulu, as well as a large number of entomological and botanical specimens. Other collections are to be distributed among scientific institutions in America and Europe, while the material relating to canoes will be submitted to Dr. A. C. Haddon in Cambridge.

\section{Regulations Concerning Chemicals}

Acrs of Parliament and Statutory Rules and Orders affecting the chemical industry are sufficiently numerous and complex to require documentation in a convenient and easily accessible form. That task has been undertaken by the Association of British Chemical Manufacturers, which in January 1931 published an index of such information. The third supplement, covering acts, rules and orders which have come to the notice of the Association during 1933 has recently been issued (Heffer, Cambridge; $6 d$. post free). New regulations regarding the packing and stowing of dangerous goods in ships have been made, and a revised edition of the summary of the principal regulations made under the Explosives Act has been issued. Reference is made to the Spirits Act, 1880, and the Still Licence Act, 1849. All plant capable of being used as a still is subject to licence, but exemptions are granted in respect of alkali works, coal gas, tar distillation, solvent recovery, chemical experiments, professional chemists, etc. Water stills of more than 1 gallon capacity require a licence; otherwise exemption may be granted on application. The supplementary index also refers, inter alia, to the Dyestuffs (Import Regulation) Act, the Import Duties Act, the Ottawa Agreements Act, the Poisons and Pharmacy Act, and the Safeguarding of Industries Act.

\section{Graph Papers}

WE have received from Messrs. Wightman Mountain, Ltd., of Artillery House, Victoria Street, Westminster, some samples of graph paper. These are of considerable interest as exhibiting the great range and variety of papers now produced in England. Of squared papers alone, Messrs. Wightman Mountain list more than 250 sizes and styles, some with ruled and others with engraved lines. A wide range of logarithmic papers includes, for example, sheets covering the ranges $7-400$ and $1-10,000$. Profile paper is specially ruled for making longitudinal sections of railways, roads, etc. Other varieties of graph paper include permille paper (arithmetic probability), square-law, polar, isocandle, triangular and isometric papers. A new paper is one ruled in tenths of an inch one way and in inches and twelfths the other. The increasing demand for the graphical presentation of commercial data has led to the publication of a number of data sheets, including daily, weekly and monthly progress sheets. Even a holiday chart is not lacking. To furnish some idea of the papers available, the firm is offering for half a crown a special sample packet of 58 different data sheets.

\section{International Agricultural Congress in Budapest}

The International Congress of Agriculture is meeting this year in Budapest on June 13-20. The Congress is held every two years in a different European capital and is attended by delegates from some thirty countries who represent every side of agricultural life. The work of the Congress is divided into eight sections. The first deals with economics and agrarian policy, world prices, the organisation of markets and the economic consequences of mechanisation. Two other sections, those on cooperation and agricultural industries, occupy parts of the same field, and the section dealing with viticulture will this year be economic rather than technical. Two sections treat respectively of animal and vegetable production from the scientific side. Modern horse-breeding, the influence of pasture on the quality of milk, contagious abortion, the production of forage crops under semi-desert conditions, plant selection, the classification of wheats and the improvement of alkaline soils are the principal subjects for discussion at Budapest. The remaining sections are to some extent social in scope, dealing with agricultural instruction and the position of women in rural communities. The Congress will be accompanied by social functions and followed by excursions, which will enable delegates to see something of educational and scientific work in connexion with Hungarian agriculture, as well as of Hungarian farming and peasant life. It is expected that a party of British delegates, connected either with agricultural science or with bodies such as the National Federation of Women's Institutes, will take part. Further information can be obtained from the secretary of the British Corresponding Committee, International Congress of Agriculture, 10 Doughty Street, London, W.C.1.

\section{Announcemerts}

Prof. J. C. McLennan will deliver the twentyfifth Kelvin Lecture before the Institution of Electrical Engineers on April 26, taking as his subject "Electrical Phenomena at Extremely Low Temperatures". Before the lecture, the Faraday Medal of the Institution will be presented to Sir Frank Smith.

Dr. C. E. Kenneth Mees, director of research to the Eastman Kodak Co., Rochester, U.S.A., will deliver the Sir Henry Trueman Wood Memorial Lecture before the Royal Society of Arts on May 16. The subject of Dr. Mees's lecture will be "Some Photographic Aspects of Sound Recording". 